\title{
Membandingkan Cetakan Terbuka Dengan Tertutup Pada Pembuatan Papan Skate Board Dari Limbah Sawit
}

\author{
M.Yani $^{1^{*}}$, Bekti Suroso ${ }^{2 * *}$ \\ ${ }^{1,2) .}$ Fakultas Teknik Universitas Muhammadiyah Sumatera Utara \\ Jalan Kapten Muchtar Basri No. 3 Medan 20238, Indonesia \\ Email :*m.yani@umsu.ac.id,**bektisuroso@umsu.ac.id,
}

\begin{abstract}
This study aims to compare open and closed molds, hand lay-up method in the manufacture of skate board boards from oil palm empty fruit bunches (OPEFB) fiber reinforced composites. The constituent materials of this composite are OPEFB fiber and unsaturated polyester resin. The mixing of both of materials with the ratio of the composition of the OPEFB fiber and polyester resin is made based on a volume fraction of 20:80. The diameter of the OPEFB fiber that is used ranges from 0.1 to $0.8 \mathrm{~mm}$ mixed into the unsaturated polyster resin liquid. OPEFB fibers are arranged longitudinally with one layer according to the thickness of the skate board. Skate board prints made using a cover have smooth surfaces on both sides. However, to ensure that the resin has filled the entire surface of the mold from a closed mold seen from the presence of resin that comes out of the closing gap. This resin can not be used anymore because it will dry up and freeze. When compared with printouts without pentup has a rough surface on the top side of the skate board. The conclusion is that the use of closed molds has better results when compared to open molds.
\end{abstract}

Key word : OPEFB fiber, composite, mold, skate board

\section{PENDAHULUAN}

Kementerian Kehutanan Republik Indonesia menyebutkan bahwa produksi kayu dari hutan tanaman industri (HTI) mencapai $46 \%$ atau 23 juta $\mathrm{m}^{3}$ dari kebutuhan kayu nasional sebanyak 49 juta $\mathrm{m}^{3}$ pada tahun 2013. Sisanya mengandalkan hutan alam. Produk kayu tanah air tidak hanya untuk keperluan perumahan saja, tetapi juga digunakan untuk pulp dan perabotan. Selain dari pada itu produk kayu tidak selalu menjadi konsumsi domestik namun juga untuk ekspor.

Diperkirakan pada tahun 2013, kebutuhan kayu untuk pulp mencapai 33,8 juta $\mathrm{m}^{3}$, perabotan 6,8 juta $\mathrm{m}^{3}$, dan kayu pertukangan 13,9 juta $\mathrm{m}^{3}$. Padahal, pada semester I tahun 2013, produksi kayu bulat hanya 1,24 juta $\mathrm{m}^{3}$. Bila diasumsikan produksi semester kedua mencapai tiga kali lipat maka total produksi kayu bulat 2013 baru berkisar 5 juta $\mathrm{m}^{3}$. Artinya, pasokan yang ada hanya mampu memenuhi $10 \%$ kebutuhan.

Pada awal tahun 2000-an, bidang konstruksi mulai mencari material alternatif pengganti kayu untuk banyak keperluan. Mereka mengganti kayu dengan baja ringan untuk rangka atap, fiber glass untuk kusen dan pintu kamar mandi, serta aluminium untuk kusen jendela dan pintu. Untuk mengatasi masalah kekurangan kayu untuk keperluan perabotan perlu dicarikan material yang lain yang mempunyai kekuatan dan karakteristik yang menyerupai kayu. Material baru yang dapat menggantikan kayu adalah material komposit alami. Material komposit alami adalah material alami yang terdiri dari dua atau lebih unsur penyusunnya untuk mendapatkan karakteristik yang lebih baik dari material penyusun itu bila dia dalam keadaan sendiri-sendiri. 


\section{Published September 2019 \\ Jurnal Rekayasa Material, Manufaktur dan Energi http://jurnal.umsu.ac.id/index.php/RMME}

Indonesia yang memiliki kebun kelapa sawit terluas di dunia. Dari hasil pengolahan kelapa sawit diperoleh minyak sawit dan turunannya yang bernilai jual tinggi. Sedangkan sisa olahan berupa tandan kosong kelapa sawit (TKKS), pemanfaatannya masih sedikit, diantaranya untuk pupuk alami tanaman di kebun-kebun sawit dan bahan bakar pada pembangkit listrik di pabrik kelapa sawit.

TKKS ini adalah limbah hasil pengolahan Crude Palm Oil (CPO) di Pabrik Kelapa Sawit (PKS) dengan jumlah yang cukup banyak, yaitu mencapai 1,9 juta ton berat kering per tahun atau setara dengan sekitar 4 juta ton berat basah per tahun. Untuk di daerah Sumatera Utara sendiri khususnya di PT. Perkebunan Nusantara III (PTPN-III) menghasilkan TKKS hingga mencapai 1350 ton basah perhari (1). Dengan demikian limbah ini dipandang memiliki potensi yang baik untuk dimanfaatkan dan dikembangkan menjadi material komposit.

Sebagai contoh pemanfaatan material ini di bidang teknologi diantaranya ialah pembuatan papan partikel (2), dan bahan baku kertas (3). Apalagi pengembangan material ini sebagai material penguat komposit PF dengan matriks berasal dari material-material polimer masih sangat jarang ditemukan. Adalah pembuatan helmet sepeda (4) parking bamper (5) kerucut lalu lintas (6) telah dikerjakan.

Dalam penelitian ini serat TKKS akan dipergunakan sebagai penguat material komposit. Selain dari pada itu, unsur penyusun dari komposit ini adalah polyester resin tak jenuh sebagai matriks. Pencampuran kedua material ini dengan rasio komposisi serat TKKS dan polyester resin dibuat bervariasi berdasarkan fraksi massa, mulai dari 5: 95 dan 10:90. Ukuran diameter serat TKKS yang dipakai berkisar antara 0,1 s.d. $0,8 \mathrm{~mm}$ yang dicampurkan kedalam cairan polyster resin tak jenuh. Serat TKKS disusun secara longitudinal dengan beberapa lapis sesuai ketebalan papan skate board. Kajian penelitian ini adalah untuk menganalisa metode terbaik dalam pembuatan papan skate board dari limbah sawit.

Secara umum material komposit terdiri dari dua bagian utama, yaitu: (1) matrik, dan (2) penguat (reinforcement). Pada penelitian ini matriks yang digunakan ialah dari jenis polimer polyester resin tak jenuh dan penguat adalah serat TKKS.

Material komposit didefinisikan sebagai campuran antara dua atau lebih material yang menghasilkan sebuah material baru dengan sifat-sifat ataupun karakteristiknya yang masih didominasi oleh sifat-sifat material pembentuknya (7). Berdasarkan definisi ini maka pemilihan jenis material yang tepat dalam penelitian ini ialah jenis material komposit, dimana yang diharapkan adalah kekuatan material yang lebih baik dari penggabungan dua atau lebih material penyusunnya.

Pada umumnya material komposit dibentuk dalam dua jenis fasa, yaitu fasa matriks dan fasa penguat. Fasa matriks adalah material dengan fasa kontinu yang selalu tidak kaku dan lemah. Sedangkan fasa penguat selalu lebih kaku dan kuat, tetapi lebih rapuh. Penggabungan kedua fasa tersebut menghasilkan material yang dapat mendistribusikan beban yang diterima disepanjang penguat, sehingga material menjadi lebih tahan terhadap pengaruh beban tersebut.

Teknik pembuatan material komposit polimer pada umumnya tidak melibatkan penggunaan suhu dan tekanan yang tinggi. Hal ini disebabkan material ini mudah menjadi lembut atau melebur (8). Proses pencampuran penguat kedalam matriks dilakukan ketika matriks dalam keadaan cair.

Metode penuangan langsung dilakukan dengan cara melekatkan atau menyentuhkan materialmaterial penyusun pada cetakan terbuka dan dengan perlahan-lahan diratakan dengan menggunakan roda perata atau dengan pemberian tekanan. Metode ini cocok untuk jenis penguat serat kontinu dan random.

Polyester resin tak jenuh adalah jenis polimer thermoset yang memiliki struktur rantai karbon panjang. Matriks ini bersifat mampu mengeras pada temperatur kamar dengan pencampuran katalis 


\section{Published September 2019 \\ Jurnal Rekayasa Material, Manufaktur dan Energi http://jurnal.umsu.ac.id/index.php/RMME}

tanpa penekanan ketika proses pembentukannya. Data mekanik material matriks diperlihatkan pada tabel 1 .

Tabel 1. Karakteristik mekanik polister resin tak jenuh.

\begin{tabular}{lcr}
\hline Sifat Mekanik & Satuan & Besaran \\
\hline Berat jenis $(\rho)$ & $\mathrm{Mg} \cdot \mathrm{m}^{-3}$ & $1,2 \mathrm{~s} / \mathrm{d} 1,5$ \\
Modulus Young $(\mathrm{E})$ & $\mathrm{GPa}$ & $2 \mathrm{~s} / \mathrm{d} 4,5$ \\
Kekuatan Tekan $\left(\sigma_{\mathrm{T}}\right)$ & $\mathrm{MPa}$ & $40 \mathrm{~s} / \mathrm{d} 90$ \\
\hline
\end{tabular}

Sumber : YUKALAC, PT. Justus Indonesia Raya

Serat TKKS ialah serat alami yang terbuat dari tandan kosong kelapa sawit yang merupakan limbah pada proses pengolahan di suatu pabrik kelapa sawit. Pada penelitian ini serat TKKS dimanfaatkan sebagai unsur penguat komposit yang dihasilkan. Tiap kandungan serat TKKS secara fisik mengandung material-material serat seperti lignin $(16,19 \%)$, selulosa $(44,14 \%)$, dan hemiselulosa $(19,28 \%)$ yang mirip dengan material kimia penyusun kayu. Sementara hasil penelitian yang telah dilakukan oleh sebuah institusi komersial terhadap komposisi material kimianya diketahui bahwa kandungan material serat dalam TKKS merupakan kandungan maksimum seperti diperlihatkan pada tabel 2 .

Tabel 2. Parameter tipikal TKKS per kg.

\begin{tabular}{rlc}
\hline No. & Material-material Kandungan & Komposisi $\mathbf{( \% )}$ \\
\hline 1. & Uap air & 5.40 \\
2. & Protein & 3.00 \\
3. & Serat & 35.00 \\
4. & Minyak & 3.00 \\
5. & Kelarutan Air & 16.20 \\
6. & Kelarutan Unsur Alkali 1\% & 29.30 \\
7. & Debu & 5.00 \\
8. & $\mathrm{K}$ & 1.71 \\
9. & $\mathrm{Ca}$ & 0.14 \\
10. & $\mathrm{Mg}$ & 0.12 \\
11. & $\mathrm{P}$ & 0.06 \\
12. & $\mathrm{Mn}, \mathrm{Zn}, \mathrm{Cu}, \mathrm{Fe}$ & 1.07 \\
\hline & T O T A L & $\mathbf{1 0 0 . 0 0}$
\end{tabular}

Berdasarkan data pada tabel 2.2 terlihat bahwa kandungan serat merupakan unsur dominan dalam TKKS. Dengan demikian TKKS diperkirakan akan memberikan sifat mekanik yang cukup baik terhadap material komposit yang dibentuk. Gambar 1. memperlihatkan TKKS yang telah dicacah menjadi bagian kecil dan serat TKKS yang terbentuk. 


\section{Published September 2019 \\ Jurnal Rekayasa Material, Manufaktur dan Energi http://jurnal.umsu.ac.id/index.php/RMME}

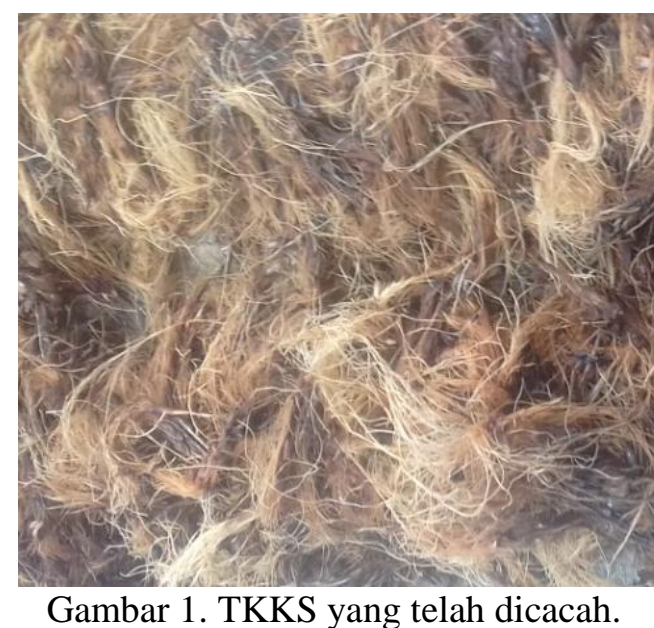

Masalah utama dalam pemanfaatan limbah kelapa sawit ialah tingginya kandungan zat ekstraktif dan asam lemak, sehingga dapat menurunkan sifat mekanik material yang dibentuk. Tandan kosong kelapa sawit segar yang dihasilkan PKS pada umumnya memiliki komposisi lignoselulosa $30,5 \%$, minyak $2,5 \%$, dan air $67 \%$. sedangkan bagian lignoselulosa sendiri terdiri dari lignin $16,19 \%$, selulosa $44,14 \%$, dan hemiselulosa 19,28\% (9). Untuk itu pada penelitian ini serat TKKS direndam terlebih dahulu ke dalam larutan $\mathrm{NaOH} 1 \mathrm{M}$ selama 1 hari, kemudian dicuci dengan air bersih, dan dikeringkan pada suhu kamar selama lebih kurang 3 hari (10). Kekuatan mekanik serat TKKS dengan diameter rata-rata $0,4 \mathrm{~mm}$ memiliki harga modulus elastisitas ratarata sebesar 11,88 GPa dengan tegangan tekan maksimum rata-rata sebesar 156,3 $\mathrm{MPa}(10)$.

Katalis Methyl Ethyl Keton Perokside (MEKP). Katalis ini merupakan material kimia yang digunakan untuk mempercepat reaksi polimerisasi struktur komposit pada kondisi suhu kamar dan tekanan atmosfir. Pemberian katalis dapat berfungsi untuk mengatur waktu atau terlalu cepat mengeras.

\section{METODE PENELITIAN}

Secara umum ada 4 tahapan utama dalam penelitian. Tahapan-tahapan tersebut yaitu tahap persiapan, pembuatan, pengujian dan penyelesaian. Tahapan digambarkan oleh fishbone diagram pada gambar 2 . 


\section{Published September 2019 \\ Jurnal Rekayasa Material, Manufaktur dan Energi http://jurnal.umsu.ac.id/index.php/RMME}

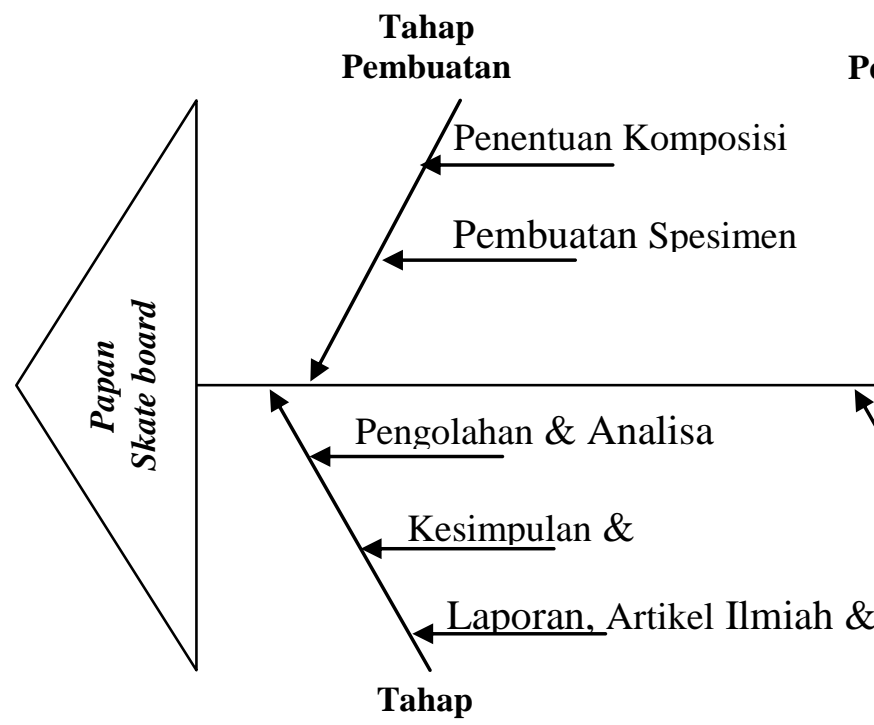

Penyelesaian
Tahap Persiapan

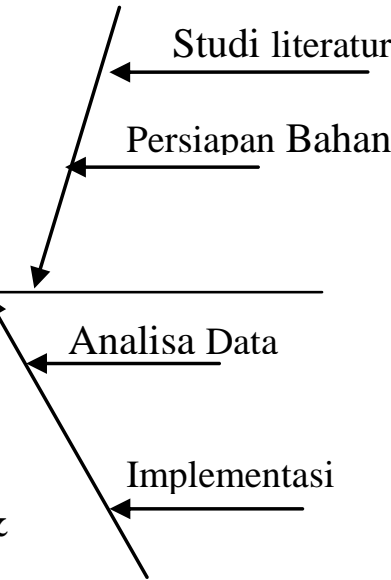

Tahap Pegujian

Material

Gambar 2. Tahapan-tahapan penelitian dalam bentuk fishbone diagram

Dalam pembuatan skate board ini menggunakan 2 cetakan seperti terlihat pada gambar 4, yaitu:

1. Cetakan terbuka

2. Cetakan tertutup

Proses pencetakan skate board dan sepesimen uji dilakukan dengan langkah-langkah sebagai berikut:

1. Oleskan lapisan pemisah pada bagian dalam cetakan dengan mold release wax agar mudah melepas produk dari cetakan.

2. Persiapan bahan-bahan yang diperlukan yaitu serat, resin tipe BQTN 157-EX yang merupakan polyester resin tak jenuh kemudian masukkan ke dalam gelas ukur volume sesuai dengan berat campuran yang ditetapkan.

3. Campurkan terlebih dahulu polyester resin tak jenuh dan serat TKKS kemudian aduk hingga merata beri kode $\mathrm{C} 1$.

4. Campurkan katalis kedalam campuran serat dan resin dan aduk hingga merata beri kode C2. Jangan biarkan C2 lebih dari 15 menit, karea ia mengeras.

5. Tuang campuran $\mathrm{C} 2$ kedalam cetakan,

6. Susun serat TKKS secara longitudinal

7. Tuang kembali campuran $\mathrm{C} 2$ kedalam cetakan dan biarkan selama 24 jam hingga benar mengeras dan kering. (pasang penutup cetakan jika menggunakan penutup)

8. Kemudian spesimen lepaskan dari cetakan. 
Jurnal Rekayasa Material, Manufaktur dan Energi, Vol. 2, No. 2, Sept 2019, 150-157

DOI:https://doi.org/10.30596/rmme.v2i2.3669

\section{Published September 2019 \\ Jurnal Rekayasa Material, Manufaktur dan Energi http://jurnal.umsu.ac.id/index.php/RMME}

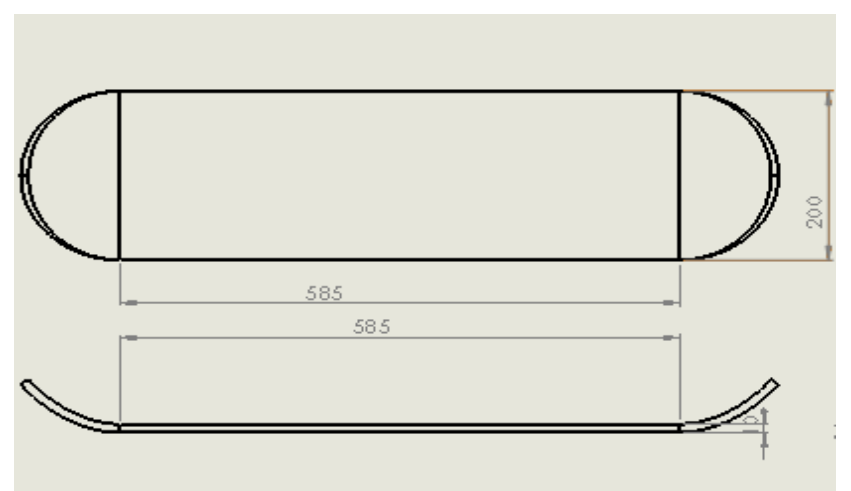

Gambar 3. dimensi skate board

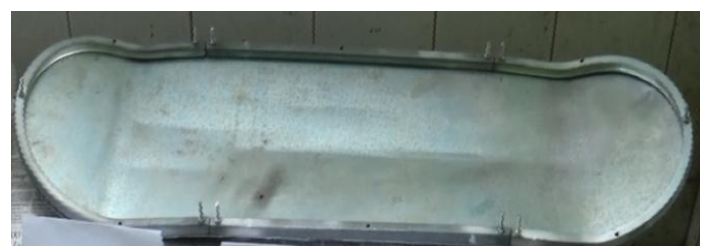

(a)

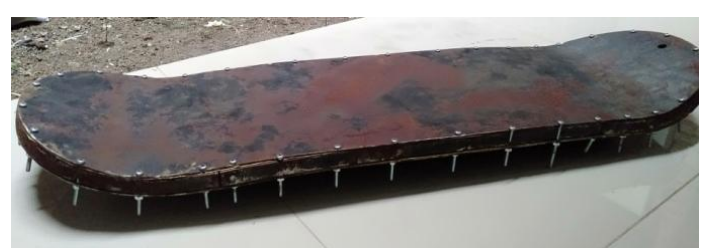

(b)

Gambar 4. cetakan skate board terbuka dan tertutup

\section{HASIL DAN PEMBAHASAN}

\section{Hasil Pembuatan Pada Papan Skateboard}

Berikut ini adalah hasil dari pembuatan papan skateboard setelah d keringkan seperti terlihat pada gambar 5 dan 6.

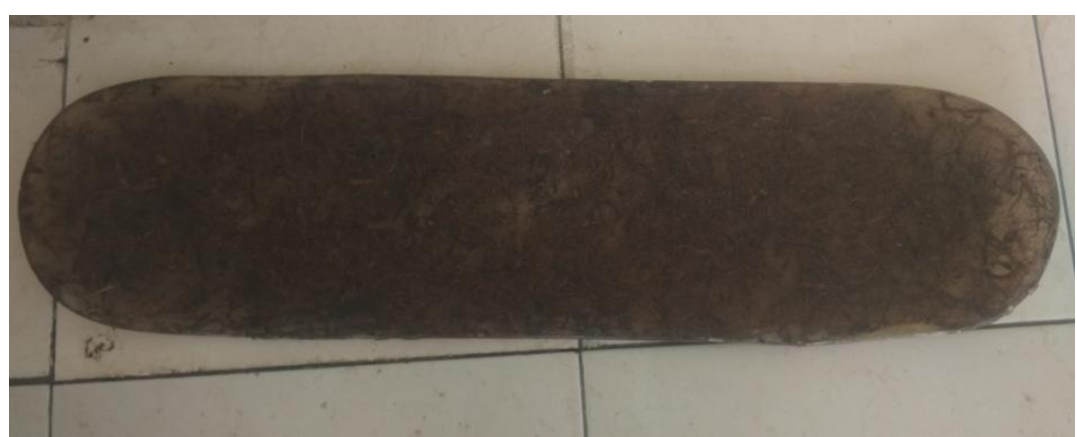

Gambar 5. Hasil pembuatan skate board dengan cetakan tertutup 


\section{Published September 2019 \\ Jurnal Rekayasa Material, Manufaktur dan Energi http://jurnal.umsu.ac.id/index.php/RMME}

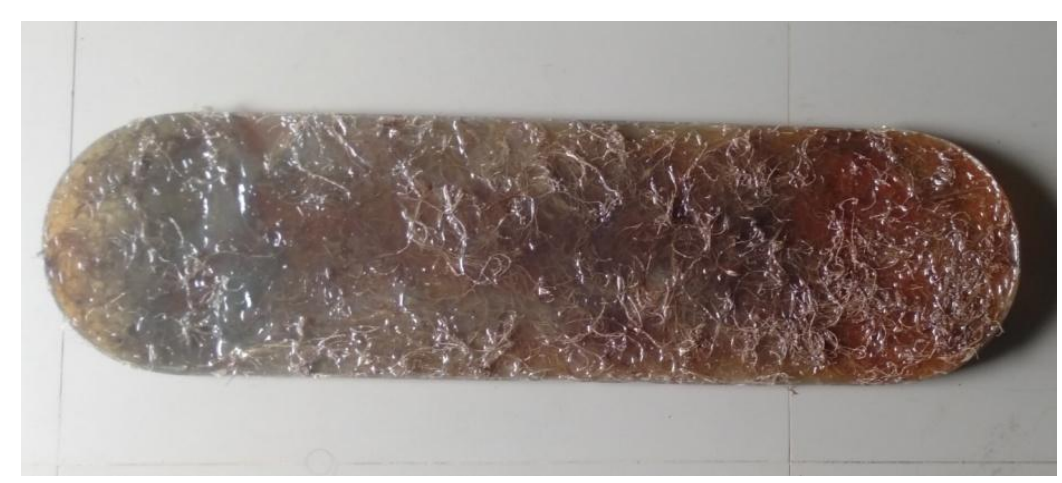

Gambar 6. Hasil pembuatan skate board dengan cetakan terbuka

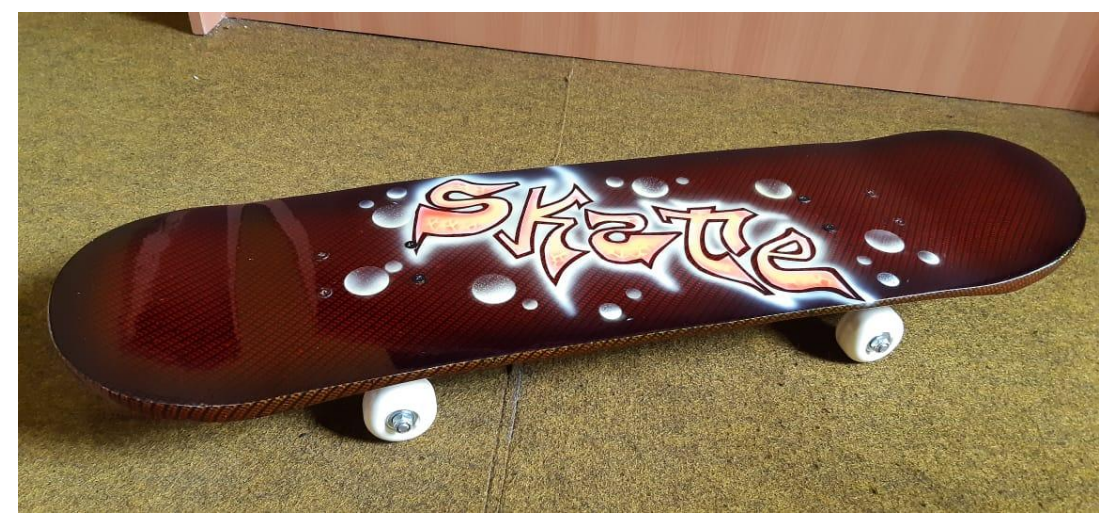

Gambar 7. Produk skate board dari bahan komposit

Proses pembuatan skate board, metode yang dilakukan adalah sama yaitu dengan metode hand lay up dan dengan komposisi yang sama pula. Pada metode ini lapisan pertama yang diberikan adalah resin yang berfungsi sebagai matriks. Selanjutnya serat tkks yang berfungsi sebagai penguat. Kemudian dilapisi dengan resin kembali untuk menutupi serat tkks. Lapisan komposit ini hanya 1 lapis.

Pada gambar 5. terlihat hasil cetakan skate board yang dibuat dengan menggunakan penutup memiliki permukaan yang halus pada kedua sisi. Namun untuk memastikan bahwa resin telah memenuhi seluruh permukaan cetakan dari cetakan berpenutup dilihat dari adanya resin yang keluar dari celah penutup. Resin yang keluar ini tidak dapat dimanfaatkan lagi karena ia akan mengering dan membeku.Jika dibandingkan dengan hasil cetakan terbuka pada gambar 6, maka skate board hasil cetakan berpenutup`lebih halus kedua sisi permukaannya, sedangkan tanpa penutup memiliki permukaan yang kasar pada sisi bagian atas skate board. Oleh karena itu yang berpenutup tidak memerlukan pekerjaan penggerindaan. Berbeda dengan yang tanpa penutup. Untuk hasil ini masih perlu pekerjaan lanjutan agar diperoleh permukaan yang halus dari skate board, yaitu prose gerinda, pengecatan dan perakitan roda seperti diperlihatkan pada gambar 7 .. 


\title{
Published September 2019 \\ Jurnal Rekayasa Material, Manufaktur dan Energi http://jurnal.umsu.ac.id/index.php/RMME
}

\begin{abstract}
KESIMPULAN
Dari hasil pekerjaan pembuatan skate board dengan metode yang sama menggunakan cetakan yang berbeda dapat diambil kesimpulan bahwa penggunakan cetakan tertutup memiliki hasil yang lebih baik jika dibandingkan dengan cetakan terbuka, yaitu tidak memerlukan pekerjaan menggerinda permukaan skate board.
\end{abstract}

\section{UCAPAN TERIMA KASIH}

Terima kasih kepada Universitas Muhammadiyah Sumatera Utara yang telah memberikan bantuan pendanaan untuk pelaksanaan penelitian ini melalui Lembaga Penelitian dan Pengabdian LPPM.

\section{DAFTAR PUSTAKA}

[1] Umar, S. Potensi Limbah Kelapa Sawit Dan Pengembangan Peternakan Sapi Berkelanjutan Di Kawasan Perkebunan Kelapa Sawit. Jurnal Wawasan, Vol 13., No.3, Tahun 2008

[2] Isroi, Pengolahan TKKS (Tandan Kosong Kelapa Sawit), (online) (http://www.isroiwordpress.com, diakses tanggal 14 April 2011).

[3] Nuryanto, E. Pemanfaatan Tandan Kosong Kelapa Sawit Sebagai Sumber Bahan Kimia. Warta PPKS : 137-144. 2004

[4] Yani, M, Desain dan pembuatan helmet sepeda bahan komposit diperkuat serat tandan kosong kelapa sawit. Tesis Master (tidak dipublikasikan), USU, 2013.

[5] Ali, S, Desain Struktur dan Pembuatan Parking Bumper Dari Bahan Polymeric Foam Diperkuat Serat Tandan Kosong Kelapa Sawit (TKKS) Terhadap Beban Impak dan Tekan, Tesis Master(tidak dipublikasikan) USU, 2012.

[6] Siswo, Pembuatan Dan Penyelidikan Perilaku Mekanik Material Polymeric Foam Diperkuat Serat Tandan Kosong Kelapa Sawit (TKKS) Akibat Beban Statik Dan Impak. Tesis Master (tidak dipublikasikan), 2010.

[7] Hashim, J., Pemrosesan Bahan, Edisi pertama, Johor Bahru: Cetak Ratu Sdn. Bhd., 2003.

[8] Gunawan, F.E., dkk, Mechanical Properties of Oil Palm Empty Fruit Bunch Fiber, Journal of Solid Mechanics \& Materials Engineering, Vol. 3., No. 7, 2009

[9] Subiyanto, Bambang, dkk. Utilization of Empty Fruit Bunch Waste from Oil Palm Industry for Particleboard Using Phenol Formaldehyde Adhesive. Warta PPKS 1-4

[10] Edward, B. Magrab, Integrated Product and Process Design and Development, New York: Cambridge University Press, 1981.

[11] Sivertsen, K., Polymeric Foam., (online) (http://ocw.mit.edu/courses/materials-science-andengineering/3-063-polymer-physics-spring-007/assignments/polymer_foams.pdf., diakses 15 Januari 2011.) 